\title{
Pemanfaatan Abu Kerak Boiler Hasil Pembakaran Limbah Kelapa Sawit Sebagai Pengganti Parsial Pasir pada Pembuatan Beton
}

Epi Prianti1) , Mariana Bara'allo Malino ${ }^{1)^{*}}$, Boni Pahlanop Lapanporo1)

\author{
1)Program Studi Fisika Jurusan Fisika FMIPA Universitas Tanjungpura \\ Jl.Prof.Dr.H.Hadari Nawawi Pontianak \\ *Email: marianabaraallomalino@physics.untan.ac.id
}

\begin{abstract}
Abstrak
Telah dilakukan penelitian tentang pemanfaatan abu kerak boiler hasil pembakaran limbah kelapa sawit sebagai bahan pengganti parsial pasir pada pembuatan beton. Pembuatan beton dilakukan dengan memvariasikan kandungan kerak boiler pada komposisi campuran beton 0\%, 5\%, 10\%, 15\%, 25\%, 50\% dan 100\%. Pengujian terhadap pasir dan abu kerak boiler meliputi uji XRF, massa jenis, penyerapan air dan kadar lumpur. Pengujian komposisi kimia dari $\mathrm{SiO}_{2}, \mathrm{CaO}$ dan $\mathrm{Al}_{2} \mathrm{O}_{3}$ pada pasir dan abu kerak boiler menggunakan XRF. Hasil analisis menunjukkan kuat tekan optimum beton dengan komposisi yang mengandung abu kerak boiler 25\% yakni 17,83 MPa. Hasil optimum dari penelitian untuk beton yang diuji tergolong dalam standar mutu tipe beton 225 yang dapat diaplikasikan pada pengecoran bangunanbangunan seperti landasan lapangan terbang, gedung bertingkat dan pengecoran jalan.
\end{abstract}

Kata Kunci :abu kerak boiler, beton, kuat tekan, uji XRF, kelapa sawit

\section{Latar Belakang}

Provinsi Kalimantan Barat merupakan salah satu penghasil kelapa sawit terbesar di Indonesia dengan luas area mencapai 5,02 juta hektar dan dengan jumlah produksi buah kelapa sawit mencapai 1.007.985 ton pertahun. Produksi kelapa sawit selain menghasilkan minyak juga menghasilkan produk samping berupa limbah kelapa sawit. Limbah yang dihasilkan dari pengolahan kepala sawit sekitar $60 \%$ dari jumlah produksi buah kelapa sawit (Mulia, 2007).

Hasil pembakaran limbah kelapa sawit menyisakan produk samping seperti abu layang sebesar kurang lebih $100 \mathrm{~kg} /$ minggu dan abu kerak boiler sekitar lebih 3 sampai dengan 5 ton/ minggu (Mulia, 2007). Sisa pembakaran abu kerak boiler yang relatif banyak tersebut dapat dimanfaatkan sebagai bahan pengganti pada batako. Hal tersebut dikarenakan kandungan yang terdapat pada abu kerak hasil pembakaran boiler dari cangkang kelapa sawit mengandung unsur kimia $\mathrm{SiO}_{2} 31,45 \%$, dan $\mathrm{CaO} 15,2 \%$ dan $\mathrm{Al}_{2} \mathrm{O}_{3}$ sebanyak 1,6\% (Jamizar, 2013). Menurut Tjokrodimuljo (1998) abu kerak boiler cangkang kelapa sawit mengandung silika yang tinggi yakni sekitar 89,9\%.

Menurut Mulia (2007) kandungan $\mathrm{SiO}_{2}$ pada pasir mencapai $90 \%$ oleh karena itu penelitian ini akan mengkaji tentang pemanfaatan abu kerak sebagai bahan pengganti parsial pasir pada pembuatan beton. Jika hendak digunakan sebagai bahan subtitusi semen, suatu material haruslah mengandung senyawa kapur dalam jumlah yang relatif besar karena pada dasarnya semen berfungsi sebagai pengikat dan yang terutama menjalankan fungsi tersebut adalah senyawa kapur. Hasil yang diperoleh Jamizar (2013) yang menggunakan abu kerak boiler sebagai substitusi semen menunjukkan nilai kuat tekan justru mengalami penurunan dan kuat tekan maksimum terjadi pada penambahan 25\% abu kerak boiler dengan nilai kuat tekan 11,3 MPa.

Variabel penelitian yang diambil adalah kadar abu kerak dalam campuran dengan komposisi adukan antara semen, pasir dan kerikil mengacu pada komposisi beton tipe 175 yang diproduksi oleh PT. Duta Indo Lestari. Parameter-parameter yang diujikan adalah kuat tekan, massa jenis pasir, massa jenis kerikil, massa jenis abu kerak, komposisi kimia pasir dan komposisi kimia abu. Kuat tekan mortar umumnya berkisar antara $3 \mathrm{MPa}$ sampai $17 \mathrm{MPa}$ dengan massa jenis antara 1,80-2,20 $\mathrm{g} / \mathrm{cm}^{3}$ (Tjokrodimuljo, 1998).

\section{Metodologi}

\section{Alat dan Bahan}

Alat-alat yang digunakan adalah ayakan agregat, penumbuk, cetakan beton ukuran $15 \mathrm{x}$ $15 \times 15 \mathrm{~cm}$, gelas ukur, neraca ohaus, batang pemadat, labu erlenmeyer dan sieve saccer. Alat pengujian yang digunakan adalah alat uji tekan, mesin pengetar (sieve saccer) yang digunakan untuk uji agregat halus dan uji berat jenis. Bahan-bahan yang digunakan adalah air, abu kerak boiler kelapa sawit, semen, pasir dan kerikil.

\section{Penentuan kandungan abu kerak boiler dan} pasir menggunakan XRF

Analisis kandungan abu kerak boiler dan pasir menggunakan instrumen XRF merk PANalytical tipe minipal 4. 


\section{Pengujian Mutu Pasir}

Penentuan massa jenis pasir diperoleh dengan cara menguji erlenmeyer dengan 500 gram agregat halus kemudian diisi air hingga agregat berada dalam keadaan saturated and surface-dry (SSD). Erlenmeyer diaduk hingga tidak terdapat gelembung udara kemudian ditambahkan air hingga batas maksimum. Erlenmeyer yang telah berisi air dan pasir direndam dalam bak perendaman selama 24 jam dan selanjutnya ditimbang, dikeringkan dalam oven dengan suhu $120^{\circ} \mathrm{C}$, didinginkan dan ditimbang kembali untuk mendapatkan bobot kering. Masaa jenis pasir dihitung menggunakan persamaan 1 (Brigita, 2012).

massa jenis $=\frac{D}{A+C-B}$

dengan A adalah bobot kondisi SSD (saturted and surface dry), B adalah bobot piknometer + air + contoh SSD saturted and surface dry), C adalah berat piknometer + air Serta D adalah bobot kering yang dinyatakan dalam gram.

Penentuan kadar lumpur pada pasir yang mengacu pada ASTM C117-30 yaitu pasir yang telah dikeringkan sebanyak 500 gram, dicuci dan ditiriskan lalu dipanaskan dalam oven pada suhu $120^{\circ} \mathrm{C}$. Kadar lumpur ditentukan berdasarkan Persamaan 2 (Brigita, 2012).

kadar lumpur $=\frac{A-B}{A} X 100 \%$

dengan A adalah bobot awal agregat (g) dan B adalah bobot akhir agregat yang telah dicuci ( $\mathrm{g}$ ).

Analisa gradasi yaitu pasir sebanyak 500 gram dimasukkan kedalam ayakan. Standar lolos ayakan bagi pasir adalah 3,75 mm.

\section{Pengujian mutu abu kerak boiler}

Pengujian mutu abu kerak boiler mengacu pada pengujian yang dilakukan pada pasir yaitu penentuan massa jenis menggunakan Persamaan 1, penentuan kadar lumpur berdasarkan Persamaan 2 dan analisis gradasi.

\section{Pengujian Bata Beton}

Pengujian serapan air yang mengacu pada Naibaho, 2009 : SNI, 1996. Beton yang sudah berumur 28 hari dibersihkan dari kotoran, kemudian ditimbang dan dicelupkan ke dalam wadah yang berisi air selama 48 jam. Sampel kemudian dikeluarkan dari perendaman, dilap dengan kain, dan ditimbang untuk mendapatkan nilai basah.

Uji tekan mengacu pada SNI, 1996. Beton ditekan hingga hancur dengan menggunakan mesin uji tekan. Penentuan kuat tekan beton dihitung menggunakan Persamaan 3.

$\sigma=\frac{F}{A}$ dengan $\sigma$ adalah tegangan ( $\mathrm{Pa}$ ), $\mathrm{F}$ adalah gaya beban $(\mathrm{N})$, dan $A$ adalah luas penampang $\left(\mathrm{m}^{2}\right)$.

\section{Pembuatan Beton}

Pembuatan adukan beton dilakukan dengan memvariasikan komposisi abu boiler dalam campuran. Semua bahan yang telah dimixer dimasukkan ke dalam cetakan yang berukuran $15 \times 15 \times 15 \mathrm{~cm}$, dipadatkan menggunakan alat pemadat beton dan hasilnya kemudian dikeluarkan dari cetakan. Beton kemudian direndam di dalam air selama masa perawatan yaitu 28 hari. Komposisi abu kerak boiler dalam pencampuran beton seperti ditunjukkan dalam Tabel 1 dengan faktor air semen adalah $0,72 \mathrm{~g} / \mathrm{cm}^{3}$.

Tabel 1 Komposisi adukan beton

\begin{tabular}{cc}
\hline Tipe & Komposisi Adukan PC:A:P:K \\
Adukan & \\
\hline I & $1: 0: 2: 3$ \\
II & $1: 0,1: 1,9: 3$ \\
III & $1: 0,2: 1,8: 3$ \\
IV & $1: 0,3: 1,7: 3$ \\
V & $1: 0,5: 1,5: 3$ \\
VI & $1: 1: 1: 3$ \\
VII & $0: 1: 2: 3$ \\
\hline
\end{tabular}

dengan PC adalah semen portland, A adalah abu kerak boiler dan $\mathrm{P}$ adalah pasir serta $\mathrm{K}$ adalah kerikil.

\section{Hasil dan Pembahasan}

\section{Karakterisasi Pasir}

Karakterisasi pada pasir bertujuan untuk mengetahui karakteristik pasir sehingga dapat diketahui kualifikasi pasir yang berpengaruh terhadap mutu beton. Karakterisasi pasir berupa penentuan senyawa utama yang dianalisis menggunakan X-Ray Fluoroscence (XRF), kadar air, massa jenis, kadar lumpur dan penggradasian pasir.

Hasil penentuan kandungan senyawa utama dalam pasir menggunakan XRF dapat dilihat pada Tabel 2.

Tabel 2 Kandungan senyawa utama dalam pasir

\begin{tabular}{cc}
\hline Senyawa & Kandungan (\%) \\
\hline $\mathrm{SiO}_{2}$ & 57.7 \\
$\mathrm{Al}_{2} \mathrm{O}_{3}$ & - \\
$\mathrm{CaO}$ & 1.54 \\
\hline
\end{tabular}

Berdasarkan penentuan komposisi kandungan senyawa utama pada pasir terlihat bahwa $\mathrm{SiO}_{2}$ mempunyai komposisi yang relatif besar. $\mathrm{SiO}_{2}$ berfungsi sebagai bahan pengisi pada pembuatan beton yang akan berpengaruh dalam kekuatan beton. 
Hasil pengujian fine modulus, massa jenis, kadar lumpur, penyerapan air pada pasir dapat dilihat pada Tabel 3.

\begin{tabular}{lccc}
\multicolumn{4}{c}{ Tabel 3 Hasil uji mutu pasir sebagai agregat } \\
halus
\end{tabular}

Sumber persyaratan: Samekto dan Rahmadiyato 200 1 ; ASTM C117-30; ASTM C128-93; ASTMC33-92a

Analisis gradasi pada pasir bertujuan mengetahui pembagian setiap butir pasir yang akan digunakan dalam pencampuran beton. Analisis ini menggunakan ayakan mulai dari ukuran $38 \mathrm{~mm}$ sampai 0,15 $\mathrm{mm}$. Menurut Paul dan Atoni (2007) gradasi yang semakin padat akan menghasilkan beton yang lebih baik dan ekonomis. Hasil fine modulus yang dihasilkan adalah sebesar 3,18. Menurut ASTM C33-92a nilai fine modulus yang baik digunakan yaitu berkisar antara 2,2-3,1 \%. Pasir pada penelitian lebih besar 0,08 \% daripada yang disyaratkan yaitu 3,1 \%. Bisa digunakan dengan pertimbangan menunjukan kondisi nyata di lapangan 3,18 \% memiliki tingkat kepadatan yang relatif baik.

Hasil penentuan massa jenis pasir pada penelitian sebesar $2,60 \mathrm{~g} / \mathrm{cm}^{3}$. Menurut ASTM C33-92 bahwa massa jenis pasir yang baik untuk pencampuran beton adalah lebih dari $2,5 \mathrm{~g} / \mathrm{cm}^{3}$ sehingga dapat dikatakan bahwa pasir yang digunakan dalam penelitian ini memiliki kerapatan molekul yang baik dan memenuhi klasifikasi sebagai bahan dasar pembuatan beton.

Menurut Samekto dan Rahmadiyanto (2001), kadar lumpur pada pasir tidak boleh melebihi $5 \%$. Kadar lumpur yang lebih dari 5\% mengakibatkan ikatan hidrogen pasta semen dan pasir berkurang akibat pengaruh lumpur sebagai pengotor. Hasil kadar lumpur pada pasir yang diperoleh adalah 1,5\% yang menunjukan bahwa pasir yang digunakan untuk memenuhi syarat dalam pembuatan beton.

Penentuan penyerapan air pada pasir bertujuan mengetahui persentase air yang diserap pasir diukur terhadap berat kering pasir tersebut. Menurut ASTM C33-92a penyerapan air yang baik untuk beton tidak lebih dari $1 \%$ dan diperoleh pada analisa kadar air yaitu $0,42 \%$. Penyerapan air yang melebihi $1 \%$ menyebabkan rongga udara yang terbentuk semakin banyak.

\section{Karakterisasi Abu Kerak Boiler}

Karakterisasi awal terhadap abu kerak boiler bertujuan untuk mengetahui karakteristik abu sehingga dapat dipakai sebagai perbandingan kualitas pasir yang diujikan.

Tabel 3 menunjukkan kandungan $\mathrm{SiO}_{2}$, $\mathrm{Al}_{2} \mathrm{O}_{3}$, dan $\mathrm{CaO}$ yang terkandung pada abu kerak boiler yang diperlukan dalam pembuatan beton. Abu kerak boiler dapat digunakan sebagai bahan pengganti pasir dalam pembuatan beton karena memiliki senyawa yang berperan dalam pembuatan beton.

Tabel 4 Kandungan senyawa utama pada abu

\begin{tabular}{cc}
\multicolumn{2}{c}{ kerak boiler } \\
\hline Senyawa & Kandungan (\%) \\
\hline $\mathrm{SiO}_{2}$ & 29,9 \\
$\mathrm{Al}_{2} \mathrm{O}_{3}$ & 1,9 \\
$\mathrm{CaO}$ & 26,9 \\
\hline
\end{tabular}

$\mathrm{SiO}_{2}$ dalam abu merupakan senyawa dengan kandungan terbesar dibanding komponen utama yang lain, sehingga dapat difungsikan sebagai pengganti pasir untuk pengisi pada pembuatan beton. Pasir dengan kandungan $\mathrm{SiO}_{2}$ yang besar dapat digunakan sebagai pengikat.

Tabel 5 Pengujian mutu abu kerak boiler bebagai agregat halus

\begin{tabular}{lccc}
\hline \multicolumn{1}{c}{ Parameter } & Satuan & Hasil & Persyaratan \\
\hline Fine modulus & $\%$ & 3,65 & $2.3-3,1$ \\
Massa jenis & $\mathrm{g} / \mathrm{cm}^{3}$ & 2,11 & $>2,5$ \\
Kadar & $\%$ & 3,6 & $<5 \%$ \\
lumpur & & & \\
$\begin{array}{l}\text { Penyerapan } \\
\text { air }\end{array}$ & $\%$ & 0,28 & $<1 \%$ \\
\hline
\end{tabular}

Sumber persyaratan: Samekto dan rahmadiyanto, 2001; ASTM C117- 30;ASTM C128-93;ASTMC33-92a.

Fine modulus yang dihasilkan abu lebih besar $0,54 \%$, dari syarat batas maksimum fine modulus agregat. Fine modulus kurang dari 2,3\% dapat dikategorikan sebagai lumpur dan di atas standar 3,1\% dapat dikategorikan sebagai agregat kasar.

Hasil massa jenis abu sebesar $2,11 \mathrm{~g} / \mathrm{cm}^{3}$, lebih rendah dari massa jenis yang dimiliki pasir. Menurut ASTM C128-93, massa jenis yang baik untuk pembuatan beton di atas 2,50 \% sehingga termasuk agregat kasar.

Pada penelitian yang dilakukan diperoleh penyerapan air pada abu sebesar $0,28 \%$. Nilai penyerapan air yang dihasilkan abu kerak boiler memenuhi syarat mencegah atau mengurangi rongga kosong dalam beton. 


\section{Pengujian Kuat Tekan}

Hasil pengujian kuat tekan beton dapat dilihat pada Gambar 1.

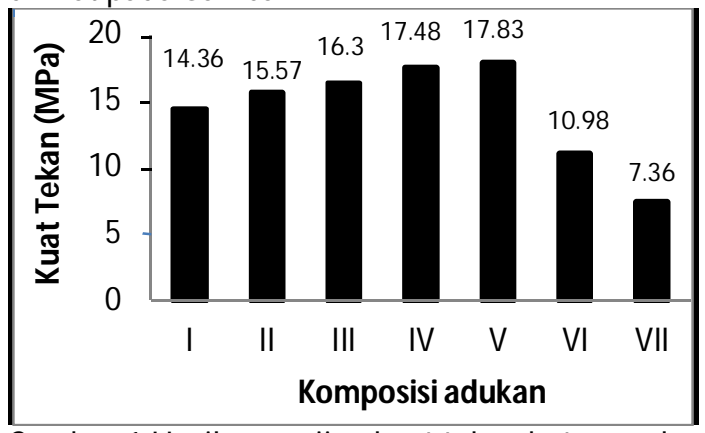

Gambar 1 Hasil pengujian kuat tekan beton pada sampel.

Hasil pada tabel menunjukkan kuat tekan yang di hasilkan semakin bertambah seiring pertambahan abu kerak boiler hingga $25 \%$ (tipe V).

Beton dengan komposisi adukan I yang menghasilkan kuat tekan sebesar 14,36 MPa, dapat diaplikasikan untuk pembuatan taman. Komposisi adukan I merupakan beton dengan mutu K175 sesuai standar PT. Duta Indo Lestari. Beton dengan komposisi adukan tipe II menghasilkan kuat tekan beton $15,57 \mathrm{MPa}$, dapat diaplikasikan untuk permukaan jalan, tipe III, IV dan V dapat diaplikasikan untuk pembuatan lantai dasar rumah, gedung bertingkat dan pengecoran jalan. Tipe VI dan VII hanya bisa diaplikasikan untuk pengecoran ringan dan tidak untuk menahan beban berat seperti sebagai paving blok, untuk tempat pejalan kaki (SNI, 1986).

Tipe adukan V menghasilkan kekuatan beton optimum yaitu 17,83 MPa. Kandungan senyawa $\mathrm{SiO}_{2}$ memegang peranan yang sangat penting dan dapat mempengaruhi kekuatan beton. Menurut Wiryasa (2008) batas maksimun kandungan $\mathrm{SiO}_{2}$ yang terdapat pasir untuk pembuatan beton berkisar 30\%, sehingga abu kerak boiler ini termasuk dalam agregat yang baik dan memenuhi standar pengganti parsial pasir.

Berdasarkan komposisi kandungan kimia, abu kerak boiler lebih unggul dibandingkan pasir karena $\mathrm{CaO}$ dalam abu berperan membantu semen sebagai bahan pengikat. Demikian pula $\mathrm{Al}_{2} \mathrm{O}_{3}$ sangat berpengaruh dalam mempercepat pengerasan pada beton.

Penurunan kuat tekan beton terjadi pada tipe VI dan VII yaitu 10,98 MPa dan 7,36 MPa. Penurunan kuat tekan pada beton tersebut dipengaruhi oleh massa jenis dan kadar lumpur. Kadar lumpur yang melebihi syarat dapat menjadi pengotor beton yang mengakibatkan ikatan hidrogen pasta semen dan pasir menjadi berkurang. Selain itu Fine modulus abu yang diperoleh pada penelitian lebih besar dari pasir, sehingga menyebabkan pembentukan rongga udara di dalam beton.

\section{Simpulan}

1. Komposisi I, II, III, IV , V memenuhi standar mutu 175 yaitu standar untuk kuat tekan 14 MPa.

2. Kuat tekan optimun diperoleh pada komposisi $\mathrm{V}$ yaitu yang menggandung $25 \%$ abu kerak boiler dengan kuat tekan 17, 83 Mpa sesuai standar mutu K225.

3. Beton pada komposisi I sampai V dapat diaplikasikan untuk pengecoran bagunan seperti gedung bertingkat dan pengecoran jalan sedangkan komposisi VI dan VII bisa diaplikasikan pada pengecoran lantai dasar bagunan.

\section{Daftar pustaka}

American Standart Testing And Material C3392a, Spesifikasi Standar untuk Agregat Beton.

Badan Standar Nasional.,1996 Standar Nasional Indonesia 03-0691 Bata Beton.

Brigita, E., 2012, Penggunaan Lumpur Hasil Pengelolahan Perusahaan Daerah Air Minum (Pdam) Sebagai Bahan Campuran Pembuatan Bata Beton, Jurusan Kimia FMIPAUniversitas Tanjungpura , Pontianak, (Skripsi).

Jamizar, Iskandar, G. R., dan Prima, Y.P., 2013, Pemanfaatan Abu Kerak Boiler Cangkang Kelapa Sawit Sebagai Bahan Tambahan (Admixture) Semen Terhadap Kuat Tekan Mortar ,Prodi Tehnik Sipil FT UNP, J. Teknik sipil 3(1).

Mulia, A., 2007, Pemanfaatan Tandan Kosong dan Cangkang Kelapa Sawit Sebagai Briket Arang, Universitas Sumutera , Medan (Tesis).

Naibaho, R., 2009, Pembuatan dan Karakterisasi Paving Block Sebagai Beton dan Kontruksi dengan Menggunakan Campuran Oil Sludge dan Semen, Fakultas Magister Sains Universitas Sumatera Utara, Medan.

Samekto, W., dan Rahmadiyanto, C., 200, Teknologi Beton, Kansius, Yogyakarta.

Tjokrodimuljo, K., 1992, Bahan Bagunan Dan Kontruksi Beton, Penerbit Keluarga Besar Mahasiswa Teknik Sipil, Universitas Gajahmada.

Wiryasa, N.M.A.; Sugita, I.N. dan Wedasana, A.S, 2008, Pemanfaatan Lumpur Lapindo sebagai Bahan Substitusi Semen pada Pembuatan Paving Block, J. Ilmiah Tehnik Sipil. 